\title{
Aspects of Reformed missiology in Africa: A contribution to A GERMAN LUTHERAN DEBATE
}

\author{
Author: \\ Ignatius (Natie) W.C. van \\ $\mathrm{Wyk}^{1,2}$
}

\section{Affiliations:}

${ }^{1}$ The Africa Institute for Missiology, South Africa

${ }^{2}$ Reformed Theological College, Faculty of Theology, University of Pretoria, South Africa

\section{Correspondence to:} Ignatius (Natie) W.C. van Wyk

e-mail:

aim1@mweb.co.za

\section{Postal address:}

The Africa Institute for Missiology, PO Box 32186, Waverley 0136, South Africa

\section{Keywords:}

Reformed missiology:

South Africa; Luther;

theologoumena;

missiological debate

\section{Dates:}

Received: 02 June 2009 Accepted: 11 June 2009 Published: 24 Aug. 2009

How to cite this article: Van Wyk, I.W.C., 2009, 'Aspects of reformed missiology in Africa: A contribution to a German Lutheran debate', HTS Teologiese Studies/ Theological Studies 65(1), Art. \#298, 10 pages. DOI: 10.4102/hts.v65i1.298

\section{This article is available}

at:

http://www.hts.org.za

\section{Note:}

This article is a slightly adapted version of a paper delivered on 21 September 2008 at a Lutheran Missionary Conference at the Bleckmarer Missionsgesellschaft, Bleckmar, Germany.

(C) 2009. The Authors. Licensee: OpenJournals Publishing. This work is licensed under the Creative Commons Attribution License.

\section{ABSTRACT}

This article is based on a paper delivered at a Lutheran Missionary Conference in Bleckmar, Germany. The request was to give an overview of the development and the state of Reformed missiology with special reference to South Africa in order to stimulate the missiological debate in the German-Lutheran church. Within the space of an hour, one could only concentrate on the struggles and concerns of one's own church and its missionary institute. The border lines of the article are laid down by the major themes of Reformed theology and missiology, such as 'the Word alone', 'conversion', 'the formation of congregations', 'the glory of God' and 'ongoing reformation'. Readers are introduced to a few Reformed missiologists who had a decisive influence on the development of Reformed missiology, such as Gisbertus Voetius, Hendrik Kraemer, Arnoldus van Ruler, Johannes Verkuyl and Jürgen Moltmann. The initial Lutheran audience was informed about the self-caused problems in the Reformed tradition. Both the audience and the readership are cautioned not to withdraw from the basic Lutheran theologoumena, such as the 'two-kingdom theory'. The next decade will be a decisive period for the missionary efforts of the churches. Ecumenical solidarity and cooperation will be needed to work out new strategies whereby churches will be enabled to continue with missionary work on a new financial basis.

\section{INTRODUCTION}

Mission is the commission of our Lord Jesus Christ (cf. at least Mt 28:16-20, Lk 9:1-9;10:1-23). The disciples and the other witnesses of his crucifixion, resurrection and ascension all obeyed this commission and therefore played an important role in the first missionary attempts by the church. The Early Church (the church of the first five centuries) and its theologians were successful in converting people to Jesus Christ, establishing congregations, apologetically defending and explaining the gospel to sceptics and critics, engaging in dialogue with people of other faiths and world views, contextualising the gospel in different social settings, humanising the world and prophetically witnessing to the public and political authorities.

The Reformed or Calvinistic churches have made valuable contributions to mission and therefore the expansion of Christendom throughout the world. At least the following countries need special mention: The Netherlands, Switzerland, Scotland, USA, South Africa, Ghana and Korea. It is therefore no surprise that Reformed theologians ${ }^{2}$ have contributed and in fact are still making important contributions to many of the missiological themes mentioned. The missiological contributions of people such as K. Barth, E. Brunner (Switzerland), R. Niebuhr (USA), J.H. Bavinck, H. Kraemer, A. van Ruler, J. Jongeneel (the Netherlands), D. Bosch (South Africa) and K. Bediako (Ghana) have stimulated missiology and mission worldwide. I am convinced that Lutheran churches could be enriched and stimulated, but should also be cautioned to listen to some of the basic notions, developments and problems of Reformed missiology. Despite many good contributions to mission and missiology, we have made many errors of judgement. We experience many difficulties and problems, ${ }^{3}$ and Lutherans would be wise to listen to them.

I use some of the basic notions of Reformed theology as well as the main arguments of the 'founder' of Reformed missiology (Gisbertus Voetius) ${ }^{4}$ as a framework for this article. I start with the well-known idea of sola scriptura and end with the idea of theologia reformata et semper reformanda. In between, the following missiological perspectives of Gisbertus Voetius will receive attention: conversion of the heathen, heretics and schismatics, (conversio gentilium), the planting of churches (plantatio ecclesiarum) and working to the glory and the manifestation of divine grace (gloria et manifestatio gratiae divinae). Some of his other, lesser known viewpoints will also receive attention. They are: a) the efforts in helping churches scattered by persecution and on the brink of financial collapse; b) the responsibility of helping

1.These aspects would, according to my understanding, form the elements of a definition on 'mission'. Amazingly, the Roman Catholic Missiology of the 20th century does not differ a great deal from this summary of Reformed missiology. According to Vatican II (1960-1964), as formulated in the decree Ad Gentes, the following aspects should receive the attention of the missiologists and missionaries: The value and function of local churches and congregations; the importance and meaning of the local cultures; the necessity of inter-religious dialogue, the promotion of liturgical adaptation and inculturation and human promotion or community necessity of inter-religious dia
development (Oborji 2006:3).

2.I accept the fact that Lutheran theologians such as Sauter (2007:166-172) have no clarity on what Reformed theology is. Instead of identifying differences between Lutheran and Reformed theology, I propose that we rather look at the similarities between Reformed theology and the Lutheran tradition. Lutherans should not regard Reformed theologians as cousins, but rather as brothers.

3.One aspect that will not receive further attention, but which needs to be mentioned, is the fact that one of the strengths of Reformed theology has also become one of its weaknesses. Reformed theology has always been renowned for its delight in innovation, new departures and interdisciplinary, cultural and ecumenical openness. However, it is exactly this approach that has led to many problems. The stress to constantly innovate is causing Reformed theology to lose its foundation. To be constantly open to all new aspects of our technological, industrialised culture leads to a superficial religiosity (cf. Welker 1999:136-137).

4. Gisbertus Voetius (1589-1676) studied theology at Leiden (the first Reformed/Hervormde faculty of theology in the Netherlands). After several years as a pastor (1610-1634), he founded the University of Utrecht where he served as professor in Semitic languages and several years as a pastor (1610-1634), he founded the University of Utrecht where he served as professor in Semitic languages and
theology (1634-1676). As we will see later on, he became the first Dutch theologian who devoted a great deal of time to missiological questions. His 'theology of mission' can be found in his Selectae Disputationes Theologicae (5 vols, 1648-1669) and Politica Ecclesiastica (3 vols, 1663-1667). 
those churches that have retrogressed theologically or that still have to develop their own theology; c) the close cooperation between the older and younger churches; $d$ ) assistance to the 'mission churches' to become the equals of the 'mother church' (Nederlandse Hervormde Kerk); and e) mission as the task of the church structures and not the trading companies. In every subsection, I will also highlight our present-day African challenges and problems.

\section{CALVINISTIC MISSIOLOGY: ORIGINS, DEVELOPMENTS, CHALLENGES AND PROBLEMS}

\section{The Word alone \\ Point of departure}

Calvinistic or Reformed theology is based on the notions of sola scriptura, sola Christum, sola gratia and sola fide. The notion of sola scriptura had an enormous influence on Calvinistic (and Lutheran) expansion in Europe and other countries around the globe. Whether one could refer to this expansion as a missionary effort is debatable. The fact remains, however, that the growth of the Reformational churches was stimulated with the translation and the distribution of the Bible in the relevant vernacular. The argument that the reformers of the 16th century did not contribute to 'mission' could, in the light of this, be proven to be wrong.

Bible translation and distribution are still the cornerstones of Calvinistic mission today (Jongeneel 1988:230). The International Bible Society is currently busy with three translation projects in South Africa and 190 in the rest of Africa. The Reformed churches play a leading role in many (if not most) translation projects. Many Reformed theologians are also involved in a number of popular Bible translations. All of them would regard their work as a contribution to the missionary task.

\section{Developments in exegesis}

The Reformed churches had a long and bitter struggle concerning obedience to the missionary commission of the Lord (Mt 28:16-20). One of the reasons for the unwillingness to engage in missionary work has to do with an exegetical issue. Theodor Beza, the successor of Calvin, ${ }^{5}$ was of the opinion that Matthew 28:16-20 was only meant for the apostles. Due to this exegesis, many Reformed churches were unwilling to obey the commission of the Lord. Adrianus Saravia (1531-1613) eventually convinced most Calvinists exegetically that this text was a commission to the church of all times (Jongeneel 1988:231). This exegetical insight of Saravia paved the way for the Reformed churches to become involved in the missio Dei trinitatis. Since the 17th century, the Reformed churches have been involved in missionary work on a massive scale.

Once the theologians removed the exegetical obstacle, people such as Petrus Plancius (1552-1622) pleaded for missionary work abroad. The question concerning mobility was an obvious focus of attention. The Reformed Church (Hervormde Kerk) in the Netherlands saw an easy solution to this problem. Because the Dutch became a leading sea-faring nation during the 17th century, the church entered into a cooperative agreement with the Dutch East India Company (Verenigde Oos-Indiese Kompanjie or VOC). The company provided the ships while the Church provided the missionaries. The decision to combine trade with mission turned the Dutch into leaders in mission and missiology. Gisbertus Voetius, the founder of the University of Utrecht, became the first Reformed 'missiologist' of note. Missiological questions became so important during his lifetime that even the National Synod of Dordrecht (1618/19) - famous for the doctrine on predestination, as recorded in the Canons of Dordt, with the philosopher René Descartes as an elder in its midst, discussed the missiological question of whether Muslim children living with Dutch people in Indonesia could be baptised. In 1622 the Dutch erected their first mission seminary, in Leiden, under Antonius Walaeus (1753-1639). The great jurist of Leiden, Hugo de Groot/Hugo Grotius (1583-1645) also made a huge contribution to missiology. In that year, he published 'Proof of the true religion' (Bewijs van de waren godsdienst). This book was used to write pamphlets for discussions with the Muslims. ${ }^{6}$ In spite of the missionary 'success' of this century, we should acknowledge the following: 'The true religion travelled with the trading industry' (De 'ware godsdienst' reist met die 'warengodsdienst' mee - Jongeneel 1988:232).

\section{Recent developments, challenges and problems}

In a country such as South Africa, the Reformed churches do not only invest millions in Bible translation projects but also in Bible distribution projects. Congregations and institutes such as the Africa Institute for Missiology (AIM) have ongoing projects, amounting to huge sums of money, to ensure that poor people in Africa receive Bibles in their vernacular.

Bible translation in Africa concerns much more than only a problem of language. ${ }^{7}$ An effort in Bible translation is also a confrontation between the culture and religion of the specific language group and the biblical text. It is therefore the first step in the difficult and dangerous processes of 'contextualisation' and 'indigenisation'. ${ }^{8}$ A Bible translation project in Africa presupposes an inter-cultural and inter-religious dialogue due to the fact that Africa is a multi-cultural and multi-religious continent where the Christian faith still has to find its way into the hearts and minds of millions.

In spite of the phrase 'the Word alone!', the training of our students and the continuing training of our ministers remains a continuous struggle with the biblical message in a setting where other cultural values and religious convictions are held in high esteem. It should come as no surprise that theological training in the Reformed tradition is mainly an ongoing confrontation between the material, cultural and spiritual worlds of our students and ministers and the Bible. Exegesis, hermeneutics and the systematic reflection on Scripture within the African context, therefore, receive high priority in our academic training. We can mention at least the following reasons for this approach:

- Many Africans, including theological students, believe that Christianity is the 'white man's religion'. It is therefore important that we develop the certainty that the 'African culture' can also stand in a positive relationship with the Christian faith. We need to convince our black brothers and sisters that 'conversion' does not mean becoming 'Westernised'.

- There is written proof ${ }^{9}$ of (but also many myths about) the early missionaries' view of the African culture as something evil. Africans are not willing to become Christians whilst there was and may still be no respect for their cultural heritage. Cautiously, the debate on a positive relationship between biblical values and the African culture must continue.

\footnotetext{
6.Jan van Riebeeck most probably had some of these pamphlets aboard his ships when sailing to the Cape of Good Hope.

7.The Presbyterian theologian of Ghana, Kwame Bediako, and his Institute (The Akrofi-Christaller Institute of Theology, Mission and Culture) have, by following in the footsteps of Kwesi Dickson, made valuable contributions regarding Bible translation and African culture (see, e.g., the special edition of Journal of African Christian Thought on this topic: JACT 10(2), December 2007).

8.Gerhard Sauter's (1998:325-335; 2007a) protest against 'contextual theology' should be taken seriously, although I am of the opinion that one can never avoid the urge for some kind of synergy between local culture and the biblical message. One can be absolutely committed to 'Biblical-Reformed theology' or 'confessiona One can be absolutely commited to 'Biblical-Reformed theology' or 'confessiona utheran theology', but still has to practice that in a context that differs from another context. We as missionaries know that traditional African culture is always a factor in our work. Sometimes it needs to be respected, while at other times it should be
}

9.cf. Bediako $(1997,1999)$ for the historical information. 
- The African renaissance movement ${ }^{10}$ concentrates on the struggle of regaining respect for the African culture and religions. Many students and pastors support this movement without keeping a critical distance. The consequence is that church leadership is constantly confused about its Christian identity.

- Not only do Africans defend their cultural and religious heritage but they also believe that their cultural beliefs and practices are closely linked to especially the Old Testament. They furthermore believe that their African culture and religions should be seen as preparations for the New Testament message (cf. Bediako 1997, 1999).

Theological methodology in Reformed academic institutions would most probably be different to a confessional Lutheran approach. We would be willing to concentrate on cultural phenomena (such as polygamy) and religious rituals (such as sacrifices) that one encounters in both the Bible and the African culture. Many of our lectures would probably end in a critical debate on an African-Christian view on the specific theme under discussion. Confessional opinions will always remain important, but the effort to 'Africanise' theology will remain part of our academic endeavours. A 'Reformed theology in Africa' is our quest.

African traditional culture and religions are not only of interest when one needs to establish a positive relationship between the African and the Bible, but also when one tries to come to a better understanding of the biblical texts by using African culture and religion. We are currently engaged in Bible studies and international research projects on a few biblical themes. One emphasis falls on the reading of the texts from an African perspective. We are trying to come to a better understanding of the texts (such as the healings of Jesus) by using our knowledge about African traditional culture and religions. Due to the similarity in cultural patterns and religious understanding, exciting insights can be discovered that would not have been gained if these texts have been read from a Western, secularised, modern or post-modern viewpoint.

Concentration on the Bible has opened up a few interesting activities that are important to African communities. On the one hand, Bible studies have made literacy projects possible to the illiterate, and have opened up the world of the Internet to the educated youth. On the other hand, young people have learned to overcome their lack of biblical knowledge by using old community rituals. Biblical themes now form the framework for these rituals. In this way, both traditional rituals and biblical knowledge are being promoted. Should this activity grow, Africa could be saved from the Western type of secularisation. ${ }^{11}$

Our theological openness to a debate on the relationship between the Bible and the local cultures and religions self-evidently creates problems concerning the relationship between Christianity and non-Western cultures and religions. Many students and pastors make the mistake of believing in the salvivic value of African culture and religions. Of course this could never be acceptable. Today, I am convinced that we should fall back on the views of the influential Reformed missiologist Hendrik Kraemer ${ }^{12}$ (1888-1965). He believed in

10.This movement is supported by many influential politicians and intellectuals such as Thabo Mbeki (1998), Es'kia Mphahlele (2004; cf. also Raditlhalo \& Lo Liyong 2006 for an overview of his life and work) and Ngila Muendane (2006)

11.My theory on secularisation is that religious rituals have been taken out of public life in the Western world. Should Africa succeed in maintaining religious rituals as the cornerstones of public life, then she could indeed become the new centre of gravity of Christendom.

12.Kraemer was born in the slum quarters of Amsterdam, where he grew up as an orphan. He was placed in a Hervormde Kerk orphanage at the age of thirteen. He had a . had a conver Leiden. Heworke for heB. He with religious literature and a Bible translation. $\mathrm{He}$ spoke out against colonialism and imperialism. At the same time he criticised the new forms of nationalism in the absoluteness of Christianity and was therefore sceptical about cooperation with other religions. He rejected syncretism as a solution to this problem. He realised that mission would always be in tension with local cultures. He therefore adopted a dialectical way to missiology. He knew that there would be continuation and discontinuation of gospel and culture, redemption and creation. In this way, he defended the right to do missionary work (a view that many people reject today). This theological stance of Kraemer has clear consequences for mission work:

- We can change the accidentals of the gospel (like liturgical forms), but not the essentials.

- The gospel must be incarnated into the local culture, but must not be overshadowed by cultural traditions.

- Young Christian communities should also adhere to the Calvinistic ideal that Christianity must cover all areas of life. Certain aspects of life, such as health and healing, cannot be excluded from the gospel (cf. Verkuyl 1978:41-51; Oborji 2006:115-116).

Finally, I believe that Voetius was correct when he stated that contributing to theological development is part of our missionary task. Amazingly, Wolfgang Huber also stated a few years ago (1998:471) that the development of theology is the ultimate goal of every missionary effort. Our task is therefore to help developing African theologians ${ }^{13}$ through motivation, support and study opportunities to work out their own answers to their problems and questions. This would only be possible when the study of the Bible and important theologians becomes their passion.

\section{Conversion}

Many people, including some missiologists, believe that conversion is an outdated idea and should no longer form part of a church's missionary effort. Biblical-Reformed missiology, however, could never abandon this notion. We cannot neglect the biblical texts that clearly expect of people to 'convert themselves' or 'to turn around' or to 'turn away from sin and evil' or to 'turn to God'. Obedience to texts such as Matthew 28 must remain part of any Reformed missiology. The fact remains, however, that conversion has become problematic, and even a controversial point of discussion among many Christians.

\section{Difficulties with conversion}

Since the Enlightenment, the notion of 'conversion' has become very problematic amongst Reformed theologians. One reason was that the Enlightenment insisted that the religions of revelation should be compared to the natural religions. Theologians were asked to compare Christ to people such as Socrates and Confucius. By doing so, one accepts the belief that Christ is not the absolute, unique redeemer and saviour. The consequence of this is that one accepts that all good heathen will go to heaven due to God's general grace. There is therefore no need for Christology and soteriology, and therefore no need for mission.

Calvinistic missiology reacted in a variety of ways to this crisis. Many Calvinists followed the route of the German Graf von Zinzendorf. According to him, the church should no longer concentrate on the corpus Christianum (the ideal to create a Christian society). We should only try to 'save receptive souls for the Lamb'. We should simply rely on the work of the Holy Spirit in 'bringing individuals to Jesus' and to leave the masses alone. They also followed his advice to go abroad, where the Enlightenment had not yet happened. There, the church could

the former colonies. In 1937, he became professor in theology at Leiden and in 1948 the first director of the WCC's Ecumenical Institute at Bossey. He was mainly responsible for the development of the close relationship between 'missiology' and 'oecumenica'.

13.Obviously, Africa has already produced excellent theologians. In many churches, however, such as the MRCC, the process of independent theologising has only begun. Churches such as these, therefore, still need support from other churches. This has nothing to do with paternalism. 
still follow an offensive strategy because at home all that was left was a defensive strategy, which in reality was not mission (Jongeneel 1988:233-235).

Another important reaction as far as conversion is concerned came from the first Dutch professor in missiology, Johannes $\mathrm{H}$. Bavinck (1895-1964). ${ }^{14}$ Bavinck was convinced that we should not run away from religious pluralism and the secularised world. We should rather expose other religions and world views as being misleading and therefore the 'wrong way'. Conversion, according to him, would be considered by others when they could be convinced of the inferiority of their own religion or world view, and of Christianity as being the 'better way'. He called this approach 'elenctics'. Elenctics, as Bavinck used it, was a more aggressive approach than 'missionary apologetics', the approach followed by the German missiologists of the 19th century.

One of the first German missiologists of the 19th century, Gustav Warneck, propagated the idea of 'missionary apologetics'. He realised that the church would have to defend and explain the gospel to people coming from other religions. He defended Christianity with the firm belief that it was the superior religion. One just had to explain this to people from other religions.

Bavinck, on the other hand, fell back on Voetius, who (with the help of Titus 1:13) expected theologians to refute and deconstruct other religions. He was convinced that Warneck's 'softer approach' would not produce positive results. He insisted on a more radical approach, namely that of convincing people of the dreadful consequences of $\sin$.

The term 'elenctics' has never been popular. Kraemer, for instance, kept on using the term 'missionary apologetics'. It was only the radical neo-Calvinist Kuyper who used this term to attack other religions as pseudo-religions that should be unmasked as sin against God. Even Bavinck's own student and successor, Johannes Verkuyl, rejected this programme. He led missiology in the opposite direction, by insisting to rather talk about 'missionary communication through dialogue and trialogue'

In my opinion, Bavinck's approach should be reconsidered. We can do so by putting the argument forward in a positive way. Elenctics, as the 'discipline of persuasion', tries to convince people of Christianity as the 'better way' by concentrating on sin and the liberation from sin. The challenge lies in finding the language that would illuminate the awfulness of sin and the freedom of the person redeemed from sin. In terms of a missionary strategy in Africa, we should leave this endeavour to the indigenous churches that understand the locals much better and could therefore use the correct words and phrases when explaining the better way of the Christian religion. Elenctics could also be the missionary tool that could lead African churches away from the unacceptable syncretistic nature of Christianity in Africa (Visser 2003:253-278).

I have indicated that it was Bavinck's successor, Johannes Verkuyl, who had realised that elenctics, as an attempt to convince people of the 'better way', would have to take the route of inter-religious and inter-cultural dialogue. The well-known 'Reformed' theologian Jürgen Moltmann also thought along these lines. Although he never used the term 'elenctics', he tried to convince people of other religions and world views of the better way, and asked them to consider conversion - reformulated in relevant terminology.

The early Moltmann (1977b) formulated conversion in an acceptable concept for those years. He described conversion as

14.Bavinck was not a member of the 'Hervormde Kerk' but of the 'Gereformeerde Kerk'. He was appointed by that Church at their faculty in Kampen. He, however, taught between 1939-1964 at the Free University in Amsterdam and during this time he became renowned. 'turning around to the future', the future of the kingdom of God. Any orientation backwards is a return to the old ideologies and idols that destroyed Europe. 'Salvation' can only come from the new possibilities that the future will offer humankind. Conversion is therefore a return to the future that can bring forth a new quality of life. The older Moltmann (1999) also accepted the fact that theology cannot reject the idea of conversion. As a person who led the way for decades in inter-religious dialogue, he also could not reject the need and necessity for dialogue. He therefore opted for a combination of the two notions. To convert people to the Christian faith, one needs to engage in dialogue on the important issues of life. Dialogue on themes that are of ultimate concern to us would only be sensible when the various spokespeople do it from their own religious perspectives. Moltmann insisted that interfaith dialogue should concentrate on 'life'. Should both parties agree to this, non-Christians could be invited to participate in the abundance of life offered by the Christian faith.

By so doing, Christian mission could totally move away from: a) spreading the Christian imperium; b) multiplying the European churches; and c) making disciples of a few individuals. Mission would then be an invitation to others to embrace God's future, the future offered to all nations. Conversion would be the acceptance of this future as a reality already present. By experiencing the fullness of life in the present, one could use that energy to improve the quality of life in this world. Jesus did not bring Christianity into the world, but new life (1 Jn 1:1-2). Christians should testify about this new life not only through words but also through deeds. The resistance against all life-threatening forces would bear witness to the work of the Holy Spirit as the 'giver of life'.

\section{Conversion in present-day Africa}

In spite of the enormous growth of the church in Africa and the loyalty of millions of people to Jesus Christ, there is great uncertainty about the commitment to the gospel and seriousness about discipleship (at least in South Africa). The following realities give rise to these concerns:

- The syncretistic nature of African Christianity (especially but not only the African Independent Churches)

- A dual religiosity that one constantly encounters

- The sacredness of the ancestor cult amongst the majority of church members

- The disloyalty to confessions and churches

- The utilistic nature of African religiosity

- The ongoing dogmatic confusion surrounding Christology and eschatology

- The lack of commitment to catechesis (the majority of our theological students did not have proper or any form of catechesis)

These realities make it imperative to concentrate on conversion in our theological training and continuing theological training of pastors. What conversion in Africa would mean remains a difficult subject. It certainly could not (only) be an acceptance of the Western lifestyle, religiosity and church practices. It should be something more 'African'. It is my personal belief that churches would have to take the following into consideration:

- Conversion in Africa would most probably be a more enthusiastic participation in the rituals and ceremonies of the church as well as the community. An inter-religious and inter-cultural dialogue with religious and cultural leaders would therefore have to precede the conversion of individuals and families. The reason: Without the cooperation and consent of the masters of ceremonies, the churches will not be allowed to use the rites and rituals of the community as a point of entrance for the gospel.

- Conversion would have to be linked to the experiences of koinonia. The experiences of 'Konvivenz' (Sundermeier 2006) would have to prepare the soil for the biblical message. 
- Conversion would most probably mean a greater communal obedience to the law of God, as formulated by the synods and ministerial meetings. However: there should be a clear insistence on obedience to the First Commandment. This would undoubtedly force the Church in Africa into a confrontation with the ancestor cult. Without this confrontation, however, conversion would remain a hollow word.

- Conversion in Africa would have to emphasise the belief in the providence of the triune God. This would also help to undermine the trust in and reliance on the ancestors.

- Converts would have to accept Christ as the mediator between man and the divine world. They would therefore have to stop relying on traditional healers for mediation.

- The pre-existence of Christ, Christ as the co-creator and Christ as the fulfilment of old prophesies could all be central dogmatic aspects, because of Africa's orientation towards the past and old things.

- New, indigenised eschatological arguments could also be important. ${ }^{15}$

\section{Formation of congregations \\ Historical developments}

The Reformed fathers were convinced that mission was the duty of the church. They also knew that mission should end up in the formation of congregations. John Calvin personally (in contrast to Theodor Beza) supported the idea that the church should do missionary work outside Europe. Calvin, however, realised that one should train people from foreign countries and then send them back to their home countries to perform such missionary duties. Fortunately, he did not have to go far to find foreign students. He concentrated on the many refugees (especially from Scotland and Hungary), who came to Geneva. Up to 141 'missionaries' were sent out to various countries in this way. According to the minutes of the minister's meeting in Geneva of the 25th August 1556, Calvin was even in favour of missionary work among the Indians in Brazil. They elected Pierre Richier and Guillaume Charretier as missionaries. The idea was that this missionary effort should form part of an emigration process of Huguenots to Brazil under the leadership of Admiral de Coligny and the French authorities. Emigration due to persecution, starting a new life with political and religious freedom and under obedience to the missionary commission, thus formed a unity. Unfortunately the expedition failed due to the Roman Catholic intervention ( $c f$. Labuschagne 2005:6).

The Reformed fathers were never in favour of the idea that mission organisations should do this work on behalf of the church. They realised, however, that the church would need the cooperation of others to succeed in this calling. Therefore, they knew that missionary activities could only succeed when they became part of something like the emigration process or trading activities. During the 17th century, this method proved to be very successful.

Unfortunately, the enthusiasm for mission work did not last very long. During the 18th and 19th centuries, the churches became reluctant to take the responsibility for mission work upon themselves. Only a few churches accepted their missionary responsibility during that time. The Scottish Presbyterian Church, Swedish Lutheran Church, and the Reformed Church in the Netherlands (due to the decision of the synod of Middelburg 1896 that recommitted its church to the missionary task) can be mentioned here. Many other churches left this responsibility to the mission societies, such as the Baptist Missionary Society founded by William Carey in 1792, which developed into the London Missionary Society founded in 1795 (as the first ecumenical missionary society).

15.Recently an old minister mentioned the possibility of dialogue on the 'new life beyond the future with the ancestors', to mention but one possibility.
The mission societies of the 19th century were renowned for three things: a) the ecumenical cooperation between mission societies that consummated in the Mission Conference of Edinburgh 1910; b) the theological approach renowned for the Réveil (revival, evangelical awakening, conversion, holiness, born-again faith and social involvement); and c) church-planting success.

The 'church-planting success' of the mission societies (many of which had some kind of link to the Reformed tradition) went hand in hand with colonial expansion (we will come back to these 'horses' that missionary efforts seemed to need to be successful). The combination between mission and colonialism self-evidently had serious consequences for the formation and growth of congregations. The missionaries as well as the local population misunderstood mission as the transferral of Western cultural achievements. Becoming a Christian was misunderstood as becoming Westernised. In Africa, men especially were not attracted to this enterprise. No wonder that African Reformed congregations are characterised by the absence of men, which has a negative impact on church growth. The theological confrontation between the gospel and traditional religions that did take place was mostly a superficial, one-sided affair. Even today, African Christianity is characterised by a dual religiosity or syncretism. Real 'church growth' can only be a growth in faith. This will not take place as long as African Christians themselves do not enter into a critical confrontation with traditional culture and religions.

Missiologists of the late 19th and early 20th centuries realised that they would have to get clarity on the relationship between the gospel and traditional religions. Two theories on traditional religions dominated discussions. British missiologists believed in an 'evolutionary theory'. They believed that Africans would eventually develop to the level of the Christian West. Faith in Christ and the question concerning the truth about the various religions were not important ( $c f$. Blenk 1990:476). European missiologists believed that Africans should break with their traditional religions when becoming Christians. They further propagated the idea that the whole population should become new people who have given up their loyalties to their old religions. Both theories were based on the belief in the superiority of the Christian West. African culture and religions were seen as 'under-developed' and inferior. In spite of the fact that millions of Africans were part of Christian congregations, one can understand the lack of commitment to the gospel because of these judgements on African humanness.

Even today, these two approaches are the cornerstones of many viewpoints on mission and missiology. Faculties of theology that still have departments of missiology still believe that conversion and the formation of congregations are important. It would be interesting to know the reasons behind the decisions of faculties to change their departments of missiology to departments of 'practical theology', 'inter-faith dialogue' or 'inter-cultural dialogue'.

Before discussing an important German voice in this regard, I wish to refer once again to Hendrik Kraemer, as he remains an important voice. In his famous book (1938) The Christian message in a non-Christian world (which was meant to be the discussion document for the 1938 conference of the International Missionary Council in Tambaram), he attacked an argument constantly used by African theologians today. He rejected the idea that Christianity is the fulfilment of the expectations of the traditional religions. ${ }^{16}$ Should this argument hold water, then conversion and the formation of congregations would not be important (cf. Blenk 1990:477). Kraemer, however, promoted the idea of 'indigenisation' - as long as the Christianity of the

16. This viewpoint, with its emphasis on dialogue and the equality of religions, is outdated for many contemporary missiologists. Hendrikus Berkhof, however, once outdated for many contemporary missiologists. Hendrikus Berkhof, however, once
said that we will eventually discover that we did not leave Kraemer behind, but that said that we will eventually discover that we did
Kraemer left us behind (cf. Blenk 1990:479). 
local 'confessing people's churches' (belydende volkskerke) covers all areas of life. He insisted that the 'mission churches' should therefore also try to 'Christianise' the whole society. This could only be done if Christianity was not seen as the continuation of traditional religions. Kraemer was one of the first missionaries who insisted that the new/young/daughter churches in the colonies should become independent, but he was aware that they would need the support of the older churches in the ecumenical world. ${ }^{17}$ This support should come from the churches and not from societies and their financial masters (Verkuyl 1978:41-51; Oborji 2006:115-116).

\section{What has been achieved?}

Most of Kraemer's pleas have become reality. The 'mission churches' became independent. 'Indigenisation' and 'contextualisation' have become the main theological exercises in the Reformed churches. Theological activities have become important. Many students and ministers are trying to develop theology in Africa. Some of his 'European' convictions, however have not taken root in African soil. The idea of Christian influence on aspects such as politics and economics seems to be an unreachable goal (at least in South Africa). It is still very difficult to enhance ecumenical cooperation in a country such as ours. Terms such as 'calling' and total commitment are still absent from the vocabulary power of many African ministers. The idea that 'mission churches' should become 'missionary churches' is still an uncomfortable idea in Africa.

\section{The formation of congregations: the end of the road?}

The formation of congregations as one pillar of Reformed missiology is starting to disintegrate. Our idea of a congregation has implied a 'full-time ministry'. For decades, we have believed that congregations could only survive if they had a full-time minister. He (or she) should then take responsibility for church services, catechesis, pastoral care, Bible studies, etc. We have also believed that the congregation itself should provide them and their family with a house and the necessary funds to live a decent lifestyle. Our problem today is that congregations can no longer support their minister with the necessary funding in this respect. Ministers, on the other hand, also want a decent civil lifestyle. The majority of them work full-time elsewhere, and only part-time in the congregation. Congregation-life has been scaled down to weekend activities (funerals on Saturdays and worship services on Sundays).

There are also other reasons why the goal of forming congregations in the 'main-line churches' has slowed down. The appeal of the African independent and charismatic churches makes 'church-growth' very difficult. The levels of poverty, the numbers of sick and dying people and the extent of the breakdown of the moral and cultural order contribute to an unwillingness to bear the responsibilities of our priesthood as believers.

This crisis confronts us with new radical questions: Do we need full-time ministers or congregations that need full-time ministry? Should we accept the secularisation of the ministry (ministry competing with a public or civil lifestyle)? Should we work in Africa with large congregations? Should we not rather follow the example of the African Independent Churches and concentrate on small 'house churches' without any property? Finally, did Luther not make a mistake by allowing ministers to marry? Is the Reformation not a mistake in itself?

At this point I wish to refer to the German missiologist Theo Sundermeier who worked in South Africa for many years. Sundermeier ${ }^{18}$ (1986) emphasised two aspects of contemporary missiology, namely dialogue and Konvivenz. No-one would disagree that both aspects are very important in respect of

17. Today, in Reformed circles, 'mission' and 'oecumenica' have become inseparable (Haak 2005)

18.cf. his student Wrogemann (1997:275-318) for a good overview of his missiology mission work. We, as South Africans, hold Sundermeier in high esteem. In the first section of this article, I have already indicated that inter-faith and inter-cultural dialogue forms a big part of my daily work. To live with the future and present ministers are just as important. The big question is however: Will dialogue and 'living together' help in the formation of congregations and keeping pastors in the ministry? Don't we need a new emphasis? Is it not more important to start talking and writing about 'calling' rather than about dialogue? The fact that we cannot keep pastors in the ministry calls for another type of discussion and another emphasis on missiological research.

\section{Doing everything to the glory of God \\ The tradition}

One of the central Calvinistic theological ideas is that we should do everything to the glory of God. The glory of God has, inter alia, to do with the renewal and transformation of individuals and society. Calvinists believe in the transforming power of the Word. They believe that obedience to the Word (as law and gospel) can transform society. Calvinists also believe in the presence of the risen Christ and his kingdom in this world. This presence also contributes to this renewal and transformation process (Leith 1993:4). We believe that renewal and transformation are not limited to private and family life. They include public and political life. Humanisation and social development are therefore part of our missiological agendas.

The Czech Reformation is most probably the best example of this Reformed relationship between faith, society and transformation ( $c f$. Lochman 1999 for a good overview). The Evangelical Church of the Czech Brethren has an exceptional place in the WARC. Its roots not only go back to the Reformation of the 16th century, but also to the reformed movements of the 14th and 15th centuries in Bohemia and Moravia. It is thus a church built on martyrdom. This Church knows that one needs social and political structures that would make it possible for the church to function as it should. Without religious freedom, respect for human dignity and the goodwill of the powerful, we cannot do everything that the Lord expects of us. Religious freedom is therefore something we have to fight for. For this reason, a church must get involved in social problems and political struggles.

\section{Recent developments}

For the past decade, Reformed missiology and mission have concentrated largely on humanitarian assistance, community development and political engagement. It is needless to say that this development has brought many good things to millions of people all over the world, but it has also plunged Reformed missiology into a deep theological crisis. In many circles, mission has ended up to be nothing more than development programmes in the Third World. It is at this point that we will have to return to the theology of Martin Luther. To explain the ecumenical importance of Luther, I wish to refer to some of the ideas of three Reformed missiologists who have paved the way for this development.

Arnoldus van Ruler ${ }^{19}$ (1908-1970) is famous for his contribution to the Dutch 'theology of the apostolate' (apostolaatsteologie). This theology did not only influence the missiology but also the church polity of the Hervormde Kerk in the Netherlands and South Africa ( $c f$. Van Ruler 1948; Nederduitsch Hervormde Kerk van Afrika 1989). Van Ruler's missiology (cf. inter alia 1954) cannot be separated from its historical setting. It was written in a time of a) many missionary activities worldwide; b) the realisation of the secularisation of the West; c) the good

19.Van Ruler was professor in systematic theology at the University of Utrecht. His missiology did not receive international recognition. The more conservative Refor (H churches in the Ne 1954). He had, howeve, a close many German scholars like Jürgen Moltmann, on whom he had a direct influence. Moltmann's Theology of hope was deeply influenced by Van Ruler. 
relationship between the Dutch and the Jewish people before, during and after the War; and d) the rise of the ecumenical movement. His missiology was therefore developed during a time when European Christians were determined to create a better social world; when they had to show the relevance of the church in an environment which had lost interest and faith in the gospel; and when the 'Third World' was receptive to the help and assistance of ecumenical movements ( $c f$. Moltmann 1976:12-33, 293-315).

One important aspect of his theology that needs to be mentioned is his new emphasis on the idea of a 'theocracy' (Van Ruler 1969; Balke 1990:224). Van Ruler saw the church as a function in the kingdom of God. The church has to serve the kingdom, and therefore has to serve the world. It can serve the world when it serves the political order and the local culture. Both these spheres need to be Christianised (kersten). Obedience to the Word by politicians and cultural leaders would serve the interests of the kingdom. This theocratic ideal opens up new perspectives on the apostolate as well as the ecclesiology. According to Van Ruler, the apostolate is not one aspect of the task of the church, but the essence (wese) of church life. The church is elected (numurus electorum) to serve the kingdom. It is responsible for proclaiming the salvation in Christ, but also for serving the world in its political and cultural appearances. The church should be instrumental in bringing politics and culture closer to the will of God as revealed in the Word. The service of the church in the world is service to God's love for the people of this world. The church is the 'cathedral of love' (cf. Balke 1990:226). Diaconics is therefore the partner of the apostolate and the apostolate can never be without the deaconate ( $c f$. Blenk 1990:482).

Van Ruler's understanding of the apostolate led him to the development of an ecclesiology that is suitable to this type of missiology (Balke 1990:228-229). He (1947:224228) used the term 'a Christ-confessing people's church' (een Christus-belijdende volkskerk). To develop a Protestant corpus Christianum, one needs to create a Christian society. This can only be done when the church influences all aspects of life of a certain people. All the peoples (Völker) therefore need churches that can influence their politics, culture and public life from a biblical perspective. To propagate this type of ecclesiology, one needs to be a great optimist. Van Ruler's optimism led him to believe that the churches could do much more than just testify about the Light that had already come. He believed that the churches could influence the political and cultural life of the peoples to the extent that the kingdom could become visible in this world.

Jürgen Moltmann, a close friend of Van Ruler, would take the argument further. ${ }^{20} \mathrm{He}$ did so in his famous book on the Christian hope (1964). In the chapter on the apostolate (1964:250-279), in which he fell back on Van Ruler's insights; he worked out the theology of world transformation through mission. Moltmann learnt from Van Ruler that mission should be discussed within the framework of eschatology and that one could never write about eschatology without writing about mission. Moltmann was convinced that even the discussion about God could never fall outside the framework of eschatology and mission (1977a:250-260). He followed Van Ruler by talking about mission as 'apostolate'. In his 'theology of the apostolate' he combined God's future kingdom, the future of the world and mission. According to him, the future is all about the new things that would and could come. What could come was a better society in which man could become humane. Mission (grounded in the resurrection of Christ) has the responsibility to contribute to this better world. Moltmann was positive about this enterprise because the world is changeable with many possibilities for something new; that would be something better (1977a:265-268).

20.Moltmann and Van Ruler and their students in Utrecht and Bonn had regular contact (cf. Moltmann 2006:71-72, 114, 256).
Johannes Verkuyl, the successor of Johannes Bavinck at Kampen, was one of the missiologists who developed the concept of the 'missionary diaconate'. He and others argued that mission is not only about spiritual needs, but also about material, social and political needs. Faith and deeds, church and social wellbeing, kingdom and the alleviation of suffering go hand in hand. No missionary effort can be without communion, love, care and help. Verkuyl tried to convince the Reformed churches to engage in the following forms of diaconia: Education, medical mission, inter-church aid, refugee help, help to political prisoners and their families, aid to victims of political violence, help to the poor, the workers, orphans and handicapped, involvement in movements for national development and contributing to political justice (Verkuyl 1978:211-221).

The critical question, however, is whether this is a dubious development. Traditional diaconate also concentrated on social and even political problems such as feeding the hungry, giving water to the thirsty, providing hospitality, giving clothes to the naked, visiting the sick and those in jails, burying the dead and creating peace between enemies (Crijns \& Elhorst 2005: 21-50). The problem with the new developments is the belief that we can contribute to a better world through the missionary diaconate. This has more to do with an ideology than the gospel, as there is no biblical proof that we can create a better world through diaconical deeds. ${ }^{21}$

\section{The glory of God and African Christianity}

In my opinion the concept 'glory of God' has not yet taken root in African Christianity ${ }^{22}$. The important role of the ancestors (as providers, as custodians of moral traditions and as mediators) might be one of the reasons for this. Where Africans do give glory to the God of the Bible, it is mostly for earthly, material and social providence. It is therefore no wonder that the 'success and prosperity preachers' are successful all over Africa. It is also no surprise that African Christians are also comfortable with the Reformed ideas about transformation, renewal and the creation of a better world.

The 'theologies of success and world improvement', however, make use of a vehicle, namely that of the ideology of world improvement and the myth that politicians, with the help of the churches, can create 'a better life for all'. ${ }^{23}$ In the light of this reality we are faced with two problems: a) mission again ${ }^{24}$ relies on the cornerstones of the dominant present-day economic ideology; and b) many people have already discovered that in spite of so many structural changes, financial assistance and developmental programmes there is no real improvement in the quality of life of the masses in the 'Third World'. A third problem can be added: The frustration with and disappointment in this ideology and myth are boiling over in all kinds of anti-social behaviour such as drug abuse, suicide and domestic violence (cf. Ncgobo 2008). This destructive behaviour will have to be on the agendas of the church. The task of theologians would at least be to identify the problems behind the problems. As mentioned already, we as South Africans will have to expose the uncritical belief in the ideology and myth that dominates

21. The belief that the church could transform the world into a better place through the deaconate was influenced by the belief of world improvement, which captured the imagination of the Western world after the collapse of the 'contemplative theodicy' and its replacement by the 'active theodicy'. When people started believing that and its replacement by the 'active theodicy'. When people started believing that
not God but man himself was responsible for the quality of life, people turned not God but man himself was responsible for the quality of life, people turned
themselves into Atlas by thinking that they could create a better world through their diaconical activities (cf. Oswald Bayer 1984:16-22, 1991:201-207).

22.I accept the disputable nature of this statement. Hopefully, missiologists would react to this.

23.Should one read with a critical eye, it is clear that understandable and acceptable political programmes in South Africa have been guided by this ideology (cf. again at Luthuli 2006 and Mbeki 1998).

24.Keep in mind that since the 17th century, mission relied on the trading industry as a vehicle. It was not only the real ships that were important, but also the economic ideology behind the ships. Today, many missiologists tend to make mission dependent again upon the ideology that believes in 'social transformation, mission dependent again upon the ideology that
development, growth, and world-improvement'. 
the political scene of the post-liberated South Africa. I am also convinced that another reason lies behind the many social problems in South Africa, and that is the uncritical belief in the modern Calvinistic 'one-kingdom-theory' (cf. Van Wyk 2005:661-670). If theologians continue to create expectations of a transformed, renewed, better world and the churches (with their non-governmental organisations) cannot fulfil those expectations, then one should not be amazed that Africans experience, for the first time, a modernistic type of theodicy crisis. ${ }^{25}$ It is exactly at this point where we need to listen to Martin Luther (and Calvin) again. His (their) theory on the two kingdoms should receive the renewed attention of the Reformed missiologists. This would hopefully prevent missiologists from raising the Christian diaconate to the level of a salvivic expectation. This theory would hopefully help us to return to the heart of Luther's theological methodology of making distinctions. ${ }^{26}$ If we do not distinguish between law and gospel, wellbeing and salvation, world and kingdom - then we will continue contributing to the emotional, social and political instability of the African people.

\section{Reformed missiology will constantly reform itself}

In Calvinistic theology we work with the dictum theologia reformata et semper reformanda. Calvinistic missiologists will therefore say missiologia semper reformanda. The reformation that we need can never be something else than a return to the Word. I am convinced that we need a Lutheran input in this regard. We need to be saved from all the new American fashion trends that Reformed people see as the solutions to modern-day problems. We need, at least, to learn again how to make fundamental distinctions in theology. Lutherans can certainly learn from Calvinists how to combine the various loci of theology in an innovative way, but we should learn from Lutherans how to keep apart what must stay apart. Our reformed or transformed missiology should be nothing less than a return to the fundamental points of departure of the Reformation. I am not pleading for less diaconal activities and social development, but for the insight that good deeds alone will not contribute to lasting growth of the African church.

Reformed missiology should not rely on what we as people can create, but on what Christ has already done for us. One can only speak about 'church growth' in Africa when there is growth in faith in the triune God. It is only through faith that there would be lasting diaconal activities that will have a lasting effect on the lives of the suffering, the poor and the sick. Presently, the missionary diaconate relies on the big donor organisations and big business (simply because the church will never be able to financially sustain all these projects). A Roman Catholic missiologist complains by saying: Missiology has the task to rethink strategies and terminology for new situations. One of the negative consequences of the missionary diaconate for Africa is the pressure on missiologists to permanently invent terminology that will attract donors. The recipients of mission in Africa, therefore, look like abject objects of cheap charity. This unity of mission, attempts of community transformation and big business have a negative impact on church growth in Africa, and should be stopped (Oborji 2006:55).

Eberhard Jüngel, who successfully combines Luther and Karl Barth, recently reminded the synod of the EKD of a few fundamental aspects about mission and evangelisation that are important enough to be repeated. Jüngel, referring to Barth (2003:117), reminds us that the church can never be seen as the end goal of God's path with us. The church is either a missionary

The African version of theodicy implies the following: Someone must be blamed fo suffering or evil. Someone with evil motives is responsible for the bad things in life. When that person (or the witch) is identified, the mystery of the tragedy, suffering or evil will be solved. It is therefore not a question of how we reconcile our faith in a loving and almighty God with the evil that we are experiencing, but rather who the person is who is responsible for the evil (cf. Van Wyk 2004). church or not a church at all. The problem, however, is what people understand under the word 'mission'. According to Jüngel, we need to bear witness about the Light that has already come. Mission is not a witness about our activities. It is a prayer that people should accept what God has already done in Christ (2003:121-123). All that we can do is to open up the eyes of people to see what they have heard from us. Deeds can certainly help to open the eyes, but mostly it would be words that would be trustworthy (2003:125-127). Gerhard Sauter, my theological father at Bonn, has the same argument. He also stresses the fact that mission is fundamentally a prayer - a prayer to accept the reconciliation in Christ (2 Cor 5:18-21). As a Lutheran, Sauter (1998:234) also agrees with Barth that missiology should be linked with the doctrine of reconciliation. This doctrine will never prevent the church from doing its diaconical duty, but will prevent it from reducing the gospel to a few socio-political activities (Sauter 1996a; 1996b).

\section{CONCLUSION}

Hopefully this overview on Reformed missiology will help us obtain clarity again on what we ought to do and what not to do. It is self-evident that we cannot give up on the classical ideas of missiology. It is also clear that there are some new initiatives that cause more problems than solutions. I hope that we as Calvinists will rediscover the importance of Lutheran theology for missiological challenges and that Lutherans will learn to appreciate the contribution of Reformed missiology in our complicated world.

The experience of ecumenical openness and solidarity gives hope for a joint effort in dealing with our big present-day problem, namely the inability to continue financing our missionary efforts the way we used to do. The declining numbers in the 'mother churches' mean that subsidies are becoming smaller. The young churches are not capable of making substantial financial contributions to their own budgets. Ministers and pastors are therefore forced into 'part-time ministries'. Today, many (if not most) black theological students use their free education as a strategy for financial survival and as an opportunity to eventually obtain employment in a state department. The less time they spend in their congregations, the less growth can be witnessed and the bigger the disinterest in the gospel becomes. White ministers and theologians are, however, the last people to criticise. During the apartheid years almost all Afrikaners were active members of one of the three Afrikaner churches because church membership secured a decent lifestyle (cf. Van Wyk 2008:604-607). Ministers benefited from this religiosity, because the ministry offered them financial security and a high standard of living. Today, we have to learn what it means to be religious without ulterior motives.

I have studied the history of our missionary tradition. I have discovered that Reformed missiology has always formed an alliance with one or more of the big cultural-historical movements of a certain period. Mission formed alliances with the trading companies during the 17th century, colonisation during the 18th and 19th centuries, the quests for social development and the creation of a better world since the late 19th century, as well as the American cultural expansion and the African renaissance during the 20 century. These alliances proved to be successful in one way and unsuccessful in another. In spite of many positives, there were always also many negatives. There is therefore no historical model on which we can fall back. We will thus have to invent innovative strategies to overcome this crisis. Mission work must continue. The question we will have to answer, however, is how we can afford it.

\section{REFERENCES}

Balke, W., 1990, 'Hoedemaker, Gunning, Kraemer \& Van Ruler', in W. Van't Spijker (ed.), De kerk: Wezen, weg en werk van de kerk naar reformatorische opvatting, pp. 202-230, De Groot Goudriaan, Kampen. 
Bayer, O., 1984, Aus Glauben leben: Über Rechtfertigung und Heiligung, Calwer, Sttutgart.

Bayer, O., 1991, Autorität und Kritik: Zu Hermeneutik und Wissenschaftstheorie, Mohr, Tübingen.

Bediako, K., [1995] 1997, Christianity in Africa: The renewal of a non-Western religion, Orbis, New York.

Bediako, K., [1992] 1999, Theology and identity: The impact of culture upon Christian thought in the second century and in modern Africa, Regnum, Oxford.

Blenk, C., 1990, 'Het zendingbevel in de 20e eeuw', in W. Van't Spijker (ed.), De kerk: Wezen, weg en werk van de kerk naar reformatorische opvatting, pp. 472-493, De Groot Goudriaan, Kampen.

Crijns, H. \& Elhorst, W. (eds.), [2004] 2005, Barmhartigheid en gerechtigheid: Handboek Diaconiewetenschap, 2nd edn., Kok, Kampen.

Ebeling, G., 1982, 'Usus politicus legis - usus politicus evangelii', Zeitschrift fur Theologie und Kirsche 79(3), 323-348.

Haak, C.J., 2005, Gereformeerde missiologie en oecumenica: Beknopt overzicht aan het begin van de 21e eeuw $A D$, De Verre Naasten, Zwolle.

Hoogleraren Kampen (ed.), 1954, De apostolische kerk: Theologische bijdragen ter gelegenheid van het honderdjarig bestaan der Theologische Hogeschool Kampen van de Gereformeerde Kerken in Nederland aangeboden door de hoogleraren, Kok, Kampen.

Huber, W., 1998, 'Auf dem Weg zu einer missionarischen Kirche', Evangelische Theologie 58, 461-479.

Jongeneel, J.A.B., 1988, 'De protestantse missionaire beweging tot 1789', in F. Verstraelen (ed.), Oecumenische inleiding in de missiologie: Teksten en konteksten van het wereldchristendom, pp. 230-236, Kok, Kampen.

Jüngel, E., [1999] 2003, 'Mission und Evangelisation', in Ganz werden: Theologische Erörterungen V, pp. 115-136, Mohr, Tübingen.

Kraemer, H., 1945, De roeping der kerk ten aanzien van de wereld en van het Nederlandsche volk, Daamen's, 'S-Gravenhage.

Kraemer, H., [1938] 1977, The Christian message in a non-Christian world, Kregel, Grand Rapids.

Labuschagne, K., 2005, 'Leiding en bydrae van Johannes Calvyn (1509-1564)', Hervormer 98(17), 6.

Leith, J.H., 1993, Basic Christian doctrine, John Knox, Louisville.

Lochman, J., 1999, 'Radical and reformed: The ecumenical contribution of the Czech Reformation', in D. Willis \& M. Welker (eds.), Toward the future of Reformed theology: Tasks, topics, traditions, pp. 406-420, Eerdmans, Grand Rapids.

Luthuli, A., 2006, Let my people go, Tafelberg, Cape Town.

Mbeki, T., 1998, Africa - the time has come: Selected speeches, Tafelberg, Cape Town.

Moltmann, J., [1972] 1976, Der gekreuzigte Gott: Das Kreuz Christi als Grund und Kritik christlicher Theologie, 3. Aufl, Kaiser, München.

Moltmann,J.,[1964]1977a, Theologie der Hoffnung:Untersuchungen zur Begründung und zu den Konsequenzen einer christlichen Eschatologie, 10. Aufl, Kaiser, München.

Moltmann, J., [1970] 1977b, Umkehr zur Zukunft, 2. Aufl, Mohn, Gütersloh. (GTB Siebenstern 154).

Moltmann, J., [1996] 1999, 'Dialogue or mission? Christianity and the religions in an endangered world', in God for a secular society: The public relevance of theology, transl. M. Kohl, pp. 226-244, SCM, London.

Moltmann, J., 2006, Weiter Raum: Eine Lebensgeschichte, Gütersloher Verlagshaus, Gütersloh.

Mphahlele, E., 2004, Es'kia continued: Literary appreciation, education, African humanism and culture, social consciousness, Stainbank, Johannesburg.

Muendane, N., 2006, I am an African: Embrace your identity, escape victimisation, Jakaranda, Pretoria.

Ncgobo, E., 2008, 'The myth of the liberation struggle and its emotional consequences among the youth of Kwazulu-Natal', Mini-dissertation, Africa Institute for Missiology, Pretoria.

Nederduitsch Hervormde Kerk van Afrika, [1951] 1989, Kerkwet en bepalings, Gutenberg, Pretoria.

Oborji, F., 2006, Concepts of mission: The evolution of contemporary missiology, Orbis, New York
Raditlhalo, S. \& Lo Liyong, T. (eds.), 2006, Es'kia: May you grow as big as an elephant and dwarf the rhinoceros, Stainbank, Rivonia.

Sauter, G., 1996a, 'Suffering' and 'Acting', in Eschatological rationality: Theological issues in focus, pp. 85-110, Baker, Grand Rapids.

Sauter, G., 1996b, 'Eschatological rationality', in Eschatological rationality: Theological issues in focus, pp. 171-200, Baker, Grand Rapids.

Sauter, G., 1998, Zugänge zur Dogmatik: Elemente theologischer Urteilsbildung, Vandenhoeck, Göttingen. (UTB 2064).

Sauter, G., 2007a, 'Contextual theology as a challenge to dogmatics', in Protestant theology at the crossroads: How to face the crucial tasks for theology in the twenty-first century, pp. 95-114, Eerdmans, Grand Rapids.

Sauter, G., 2007b, 'Observations on the current state of Reformed theology', in Protestant theology at the crossroads: How to face the crucial tasks for theology in the twenty-first century, pp. 166180, Eerdmans, Grand Rapids.

Spindler, M., 1988, 'Bijbelse fundering en oriëntasie van zending', in F. Verstraelen (ed.), Oecumenische inleiding in de missiologie: Teksten en konteksten van het wereldchristendom, Kok, Kampen.

Sundermeier, T., 1986, 'Konvivenz als Grundstruktur ökumenischer Existenz heute', in D. Ritschl (Hrsg.), Ökumenische Existenz heute 1, pp. 49-100, Kaiser, München.

Sundermeier, T., 2006, 'Zusammenleben mit Menschen verschiedener Religionen und Kulturen', in R. van Hempelmann (Hrsg.), Leben zwischen den Welten, pp. 42-57, EZW, Berlin. (EZW-Texte 187).

Van Ruler, A., 1947, Droom en gestalte: Een discussie over de theologische principes in het vraagstuk van Christendom en politiek, Holland, Amsterdam.

Van Ruler, A., 1948, Het apostolaat der kerk en het ontwerp-kerkorde, Callenbach, Nijkerk.

Van Ruler, A., 1954, Theologie van het apostolaat, Callenbach, Nijkerk.

Van Ruler, A., [1956] 1969, Theocratie en tolerantie, in Theologisch Werk. Deel I, pp. 191-215, Callenbach, Nijkerk.

Van Ruler, A., [1950] 1978a, 'De grondvragen van de zending in het licht der eschatologie', in Verwachting en voltooiing: Een bundel theologische opstellen en voordrachten, pp. 81-99, Callenbach, Nijkerk.

Van Ruler, A., [1960] 1978b, 'Barmhartigheid en gerechtigheid', in Verwachting en voltooiing: Een bundel theologische opstellen en voordrachten, pp. 161-175, Callenbach, Nijkerk.

Van't Spijker, W. (ed.), 1990, De kerk: Wezen, weg en werk van de kerk naar reformatorische opvatting, De Groot Goudriaan, Kampen.

Van Wyk, I.W.C., 2004, 'African witchcraft in theological perspective', HTS Teologiese Studies/Theological Studies 60(4), 1201-1228

Van Wyk, I.W.C., 2005, 'The political responsibility of the church: On the necessity and boundaries of the theory of the two kingdoms', HTS Teologiese Studies/Theological Studies 61(3), 647-682.

Van Wyk, I.W.C., 2008, 'Apologie vir die Christelike lewenswyse en etiek', HTS Teologiese Studies/Theological Studies 64(1), 599-629.

Verkuyl, J., [1975] 1978, Contemporary missiology: An introduction, transl. D. Cooper, Eerdmans, Grand Rapids.

Verstraelen, F. (ed.), 1988, Oecumenische inleiding in de missiologie: Teksten en konteksten van het wereldchristendom, Kok, Kampen.

Visser, P., 2003, Heart for the gospel, heart for the world: The life and thought of a reformed pioneer missiologist Johan Herman Bavinck (1855-1964), Wipf \& Stock, Eugene.

Welker, M., 1998, 'Missionarische Existenz heute', Evangelische Theologie 58, 413-424.

Welker, M., 1999, 'Travail and mission: Theology reformed according to God's Word at the beginning of the third millenium', in D. Willis \& M. Welker (eds.), Toward the future of Reformed theology: Tasks, topics, traditions, pp. 136-152, Eerdmans, Grand Rapids. 
Wind, A., 1988, 'De protestantse missionaire beweging van 1789 tot 1963', in F. Verstraelen (ed.), Oecumenische inleiding in de missiologie: Teksten en konteksten van het wereldchristendom, pp. 230-236, Kok, Kampen.
Wrogemann, H., 1997, Mission und Religion in der Systematischen Theologieder Gegenwart: Das Misionsverständnis deutschsprachiger protestantischer Dogmatiker im 20. Jahrhundert, Vandenhoeck, Göttingen. 